\title{
$\underline{\text { Explaining voter turnout rates in new democracies: Guatemala }}$
}

By: Fabrice Lehoucq and David L. Wall

Lehoucq, Fabrice and David L. Wall. "Explaining Voter Turnout Rates in New Democracies: Guatemala," Electoral Studies, Vol. 23, No. 3 (September 2004): 485-500.

Made available courtesy of ELSEVIER:

http://www.elsevier.com/wps/find/journaldescription.cws_home/30412/description\#description

\section{***Note: Figures may be missing from this format of the document}

\begin{abstract}
:
This paper uses several ols models to evaluate the impact of sociological, institutional, and spatial approaches to turnout across the 330 municipalities of Guatemala. It shows that economic development and geographic location (urban vs. rural) have little discernible impact on turnout. Turnout, however, varies positively with the share of registered voters who are female, even if fewer women are registered to vote and, as a result, actually cast ballots. As turnout has fallen through time, the share of registered voters who are literate and the share of the population that is indigenous have become negatively associated with turnout. Larger number of citizens turn out to vote as municipal size decreases and as the ratio of registered voters to voting stations falls. That these factors are significant suggests that, even in a research design that privileges socioeconomic variation, spatial-institutional differences help explain voter turnout rates. Keywords: Voter turnout; Political participation; Democratization; Guatemala
\end{abstract}

\section{Artice:}

\section{Introduction}

In the study of voter turnout rates, we know two sets of facts. One is sociological: numerous survey researchers show that, at the individual level, turnout varies positively with wealth and education (see Lijphart, 1997, for a review). The other is institutional: the more competitive and accountable the political systems are, the larger the turnout rate is (Cox, 1999; Jackman, 1987; Jackman and Miller, 1995). These are findings largely drawn from national-level studies of industrial democracies. How both sets of factors interact in the developing world, however, is largely unknown.

We use a subnational research design to uncover the social and institutional underpinnings of voter turnout in Guatemala. By analyzing turnout at the municipal level, we can vary the social conditions that are held constant in most cross- national research on voter turnout rates while nevertheless employing the institutional variation necessary to evaluate the consequences of electoral laws. We also pioneer the use of three new spatial-institutional variables that measure the effects of location, distance, and jurisdiction on turnout rates - factors that geographers claim are as important as any other on a whole host of political and social outcomes (Agnew, 1996; Dorling et al., 1996; Hodge and Staeheli, 1992). In this paper, we also present novel estimates of the size of the electorate-all adults 18 or older-at the municipal level with easily replicable demographic techniques. 
Like many other new democracies, Guatemala is ethnically complex and economically stratified. Approximately half of the population speaks one of the two-dozen Maya languages. About half of the population lives in rural areas. According to the UN Development Program, 1999 GDP per capita (PPP) was $\$ 3,674$ (UNDP 2000) — placing it 92nd out of 162 countries the UNDP ranked. Guatemala also has witnessed low levels of voter involvement in politics. Since the transition from dictatorship in 1985, turnout has fallen from $49 \%$ to $30 \%$ of all eligible voters in 1995 . Indeed, Guatemala ranks as one of the least participatory political systems in the world (IDEA, 1997), a fact that political economists believe is causally linked to low levels of government spending and support for democracy (IDB, 2000: 163-99; Seligson, forthcoming).

In brief, we show that institutional factors shape turnout, even in a subnational research design that maximizes sociological variation. Most importantly, we find that turnout falls as municipal (territorial) size and the ratio of registered voters to voting stations increases. By 1995, in fact, turnout was falling by $1 \%$ for every increase of approximately 10 registered voters per voting station. All things being equal, requiring citizens to cast ballots only in the capital of the municipality of residence (regardless of where they live in the countryside or nearby settlements) - where, on average, less than $30 \%$ of the municipal population lives - maintains low turnout rates in Guatemala. We find that turnout varies positively with the share of registered voters who are female. Even when controlling for other factors, economic development and geographic location (urban vs. rural) have few discernible effects on turnout. And, as turnout rates have fallen through time at both the national and municipal levels, the share of registered voters who are literate and the share of the population that is indigenous have become negatively associated with turnout rates.

The first section contains an overview of Guatemalan politics and its institutional arrangements. Subsequently, this paper identifies alternative hypotheses about turnout, presents our variables, specifies regression models, and discusses their results. In the conclusion, we explore how low turnout rates contribute to the political economic "trap" in which Guatemala is stuck - that of low taxes,

$\begin{aligned} & \text { Table 1 } \\
& \text { Voter turnout rates, } \\
& \text { 1985-1995 }\end{aligned}$
\begin{tabular}{lllllll}
\hline Election & $1985(\%)$ & & $1990(\%)$ & & $1995(\%)$ & \\
\cline { 2 - 7 } & $\begin{array}{l}\text { As a share } \\
\text { of eligible } \\
\text { voters }\end{array}$ & $\begin{array}{l}\text { As a share } \\
\text { of registered } \\
\text { voters }\end{array}$ & $\begin{array}{l}\text { As a share } \\
\text { of eligible } \\
\text { voters }\end{array}$ & $\begin{array}{l}\text { As a share } \\
\text { of registered } \\
\text { voters }\end{array}$ & $\begin{array}{l}\text { As a share } \\
\text { of eligible } \\
\text { voters }\end{array}$ & $\begin{array}{l}\text { As a share } \\
\text { of registered } \\
\text { voters }\end{array}$ \\
\hline $\begin{array}{lllllll}\text { Presidential } \\
\text { Legislative }\end{array}$ & 49 & 69 & 39 & 56 & 30 & 47 \\
Presidential runoff & 46 & 69 & 39 & 56 & 31 & 47 \\
\hline
\end{tabular}

social expenditure shortfalls, and unresponsive and thus undervalued governments.

\section{Political competition, electoral laws, and turnout in Guatemala}

The rules governing political competition are contained in the 1985 constitution and its 1994 amendments. In place of four-year terms of office for presidents andmembers of the unicameral legislature, the 1994 reforms instituted five-year terms of office. The Supreme 
Electoral Tribunal convenes a runoff between the two candidates garnering the most votes if no candidate obtains an absolute majority of the vote in the first round. Citizens elect deputies from multimember districts that are identical to the country's 22 departments and the separate district of Guatemala City (for a total of 23 districts). They continue to be allowed to run for reelection and to serve concurrent terms with the president. The number of deputies elected from each department varies according to the population of the department (Lehoucq, 2002).

Comparatively low and declining voter turnout rates plague Guatemalan elections. Even the year with the highest turnout rates - that of 1985just half of all eligible voters went to the polls. Approximately $70 \%$ of eligible voters - all men and women 18 years or older-are actually registered to vote. Only literate citizens are required to register to vote. Table 1 contains national level turnout rates between 1985 and 1995.

The first of two comments to be made about these figures is that they are low by regional and international standards. Within Central America, only El Salvador has turnout rates as low as Guatemala's (Seligson et al., 1995). In Costa Rica, Honduras, and Nicaragua, turnout hovers between $75 \%$ and $80 \%$ of the voting-age population. Second, these figures conceal an enormous amount of variation among municipalities - the jurisdictional level at which the Supreme Electoral Tribunal begins to aggregate votes. According to the 1994 Population Census, almost half of the municipalities (164) are 50 or more percent ladino - an ethnic category best defined as not indigenous. Slightly over half of the municipalities (166) are pre-

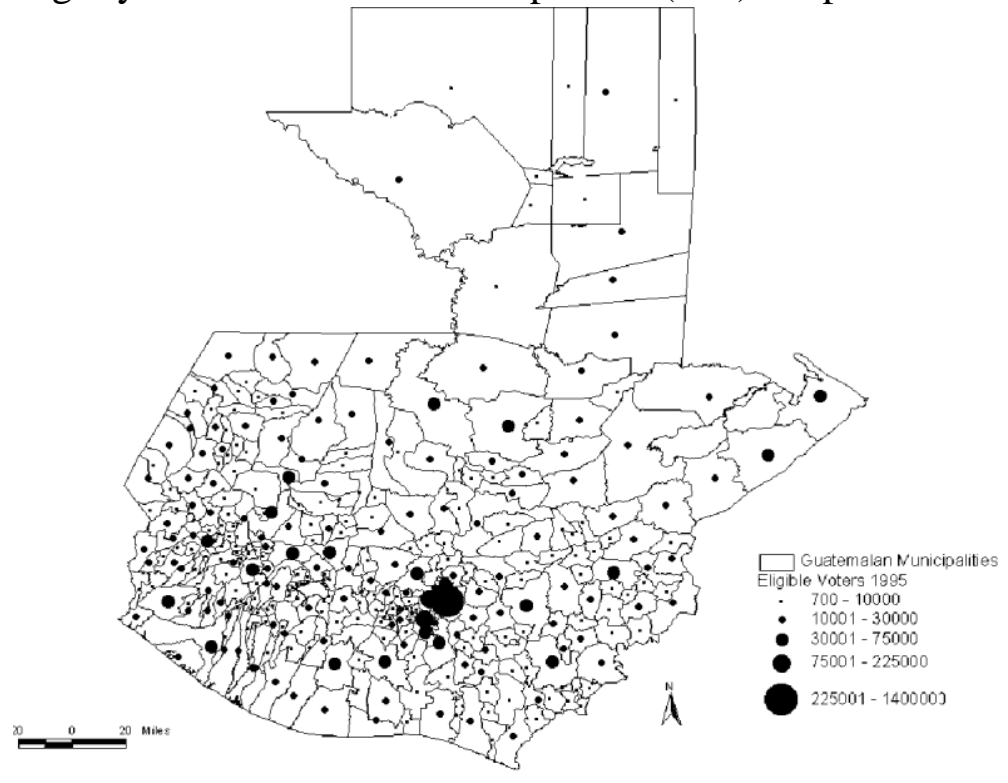

Fig. 1. Map of the distribution of eligible voters among municipalities.

dominately indigenous. ${ }^{1}$ Using 1995 estimates, Fig. 1 shows the distribution of eligible voters. Guatemala City dominates the electoral map; it contains almost $20 \%$ of all eligible voters. After

\footnotetext{
${ }^{1}$ There were 330 municipalities in Guatemala at the time of the 1985 elections. However, we only used 325 for the 1985 regression analysis because, in the first place, data for the three municipalities created between the 1981 census and the 1985 elections are incomplete. In the Department of Quiche', Chicama'n was split off from Uspanta'n and Ixca'n was created from Chajul. In the Department of Pete'n, Santa Elena was split off from Flores. In the second place, voter registration data are unavailable for Zaragoza in Chimaltenango and Zapotitla' $n$ in Jutiapa.
} 
removing Guatemala City, the average number of eligible voters per municipality in 1995 was 13,226 , with a standard deviation of 17,049 .

\section{Research hypotheses and variables: theory and measurement}

If sociological approaches are correct, then turnout should be higher as the percent of the municipal population is more "modern." This approach sees voters essentially predisposed to turning out to vote because support of democracy is said to vary with levels of education and wealth (Verba and Nie, 1972; Wolfinger and Rosenstone, 1980).

Standard sociological variables include the percentage of a municipality's population that is urban, that has access to electricity, and that is literate. We measure the effects of economic development by using the percentage of households with electricity because no municipal-level data exist on GDP rates. Since communities must fund part of the money necessary to bring electricity to their settlements, the share of homes in a municipality with electricity is a useful proxy for assessing the relative wealth of communities across Guatemala. Modernization theory also expects turnout rates to vary positively with literacy rates. Finally, we use the share of the registered electorate that is female as a surrogate measure of women's status within society. So, if modernization theory is useful, turnout should vary positively with the share of the registered electorate that is female.

There are at least two interpretations of the role of indigenous communities in voter turnout rates. In line with modernization theory, one account argues that political participation will be lower among indigenous peoples because they belong to local, less participatory political cultures. Another, rather different perspective contends that turnout rates will be higher among indigenous peoples in Guatemala because they have a long history of local decision-making, solidarity, and autonomy (Smith, 1990).

The data for spatial location, electricity, and indigenousness stem from official census sources: the 1981 figures are from the General Directorate of Statistics (DGE, 1982a; DGE, 1982b) and those from 1994 from the National Institute of Statistics (INE). Unlike the other sociological variables, literacy and gender are expressed as shares of registered voters. Data on the literacy and gender of voters are from the Supreme Electoral Tribunal (TSE, 1986) and are available for each election.

A second view is more political. It assumes that, whatever the sociological predisposition of individuals to vote, the basic characteristics of a political system powerfully shape voter turnout rates. This approach suggests that turnout varies as a political system becomes competitive, automatically registers its citizens, and as the ratio of votes to seats approaches equality (Jackman, 1987; Jackman and Miller, 1995; Powell, 1986). The theoretical assumption of these studies is that citizens are more likely to become voters as the cost of casting a ballot declines (Colomer, 1991).

We use several measures of political-institutional arrangements from cross- national research on turnout. We hypothesize that turnout increases with proportionality because the incentives for parties to mobilize voters are greater as the value of public office increases. Voters will be more likely to turnout if their votes determine the fate of a larger share of legislative deputies. 
Modifying Powell (1986: 38), we assign each municipality a score corresponding to its district magnitude or the number of representatives its department elects.

The next measure of institutional impact is the vote-seat deviation. From Lijphart (1994), we measure the difference between the percentage of votes received from the percentage of seats for the two largest parties in each department. According to Jackman (1987), the disproportionality of a voting system varies inversely with turnout: as the number of wasted votes increases, parties and citizens become disinclined to vote. Again, we assign the difference between the percentage

Table 2

Descriptive statistics for independent and dependent variables

\begin{tabular}{|c|c|c|c|c|c|}
\hline Variables & Minimum & Maximum & Mean & Median & $\begin{array}{l}\text { Standard } \\
\text { deviation }\end{array}$ \\
\hline & 1985 & 1985 & 1985 & 1985 & 1985 \\
\hline & 1990 & 1990 & 1990 & 1990 & 1990 \\
\hline & 1995 & 1995 & 1995 & 1995 & 1995 \\
\hline \multicolumn{6}{|l|}{ Turnout (votes/eligible voters) } \\
\hline \multirow[t]{3}{*}{ Presidential } & 16.0 & 89.8 & 49.0 & 49.4 & 11.1 \\
\hline & 11.1 & 74.8 & 41.5 & 41.3 & 11.6 \\
\hline & 11.8 & 84.5 & 39.2 & 38.2 & 13.2 \\
\hline \multirow[t]{3}{*}{ Legislative race } & 16.0 & 90.0 & 48.9 & 49.2 & 11.1 \\
\hline & 11.1 & 74.8 & 41.5 & 41.6 & 11.6 \\
\hline & 11.8 & 83.8 & 39.3 & 38.3 & 13.2 \\
\hline \multirow[t]{3}{*}{ Presidential runoff } & 16.2 & 80.5 & 44.6 & 44.8 & 11.7 \\
\hline & 6.9 & 58.8 & 30.8 & 31.2 & 10.2 \\
\hline & 7.1 & 56.9 & 26.2 & 26.3 & 9.4 \\
\hline \multirow[t]{3}{*}{ Eligible voters } & 369 & 675,591 & 12,019 & 6971 & 38,500 \\
\hline & 567 & 947,817 & 14,331 & 7679 & 53,577 \\
\hline & 710 & $1,328,204$ & 17,211 & 8830 & 74,362 \\
\hline \multicolumn{6}{|l|}{ Sociological variables } \\
\hline \multicolumn{6}{|l|}{ Urban population } \\
\hline 1994 & 1.5 & 100.0 & 28.8 & 22.2 & 22.7 \\
\hline 1981 & 1.3 & 100.0 & 27.7 & 20.2 & 23.4 \\
\hline \multicolumn{6}{|l|}{ Indigenous population } \\
\hline 1994 & 0.2 & 99.5 & 49.7 & 51.2 & 38.1 \\
\hline 1981 & 0.3 & 99.8 & 50.7 & 53.4 & 38.2 \\
\hline \multicolumn{6}{|l|}{ Share of households w/electricity } \\
\hline 1994 & 1.9 & 97.1 & 46.3 & 47.2 & 27.4 \\
\hline 1981 & 0.0 & 83.5 & 19.3 & 14.7 & 17.3 \\
\hline \multirow{3}{*}{ Females (as a share of registered voters) } & 2.8 & 59.9 & 36.3 & 39.3 & 10.7 \\
\hline & 3.3 & 51.8 & 36.6 & 39.8 & 9.4 \\
\hline & 5.5 & 53.3 & 40.0 & 40.6 & 8.6 \\
\hline \multirow[t]{3}{*}{ Literates (as a share of registered voters) } & 5.5 & 92.6 & 51.4 & 54.4 & 18.5 \\
\hline & 10.7 & 93.4 & 54.7 & 57.9 & 18.3 \\
\hline & 15.9 & 94.2 & 58.1 & 61.5 & 17.6 \\
\hline \multicolumn{6}{|l|}{ Institutional variables } \\
\hline \multirow[t]{3}{*}{ District magnitude } & 2 & 10 & 3.4 & 3.0 & 1.6 \\
\hline & 2 & 10 & 4.0 & 4.0 & 1.7 \\
\hline & 1 & 9 & 3.0 & 3.0 & 1.7 \\
\hline \multirow[t]{3}{*}{ Effective number of parties } & 1 & 3.6 & 2.1 & 2.0 & 0.8 \\
\hline & 1 & 4.5 & 2.8 & 2.8 & 0.8 \\
\hline & 1 & 4.2 & 2.2 & 2.0 & 1.0 \\
\hline Closeness & 0.02 & 30.7 & 7.3 & 5.7 & 6.2 \\
\hline \multirow[t]{2}{*}{ Presidential } & 0.03 & 16.9 & 4.0 & 3.0 & 3.5 \\
\hline & 0.0 & 24.1 & 4.5 & 3.5 & 4.1 \\
\hline \multirow[t]{3}{*}{ Legislative } & 0.009 & 30.2 & 6.2 & 4.1 & 5.8 \\
\hline & 1.28 & 19.3 & 3.6 & 2.6 & 3.5 \\
\hline & 0.02 & 22.39 & 4.1 & 2.9 & 4.0 \\
\hline
\end{tabular}


Table 2 (continued)

\begin{tabular}{llllll}
\hline Variables & Minimum & Maximum & Mean & Median & $\begin{array}{l}\text { Standard } \\
\text { deviation }\end{array}$ \\
\hline Presidential runoff & & & & & 15.8 \\
& 0.00 & 54.7 & 16.1 & 11.2 \\
& 0.16 & 30.0 & 10.2 & 9.7 & 6.0 \\
& 0.01 & 18.7 & 5.3 & 4.2 & 4.1 \\
Spatial-institutional variables & & & & & \\
Size of municipality & 1.8 & 3172.3 & 126.8 & 51.4 & 293.0 \\
Ratio of registered voters to voting stations & 257.0 & 1281.5 & 486.8 & 479.4 & 81.1 \\
& 225.0 & 599.8 & 529.6 & 563.8 & 68.1 \\
& 327.5 & 599.9 & 567.5 & 577.1 & 35.6 \\
\hline
\end{tabular}

of votes and seats obtained by the two largest parties in each department to each of its municipalities.

The third institutional measure is the index of Laakso and Taagepera (1979) of the effective number of parties. According to Jackman (1987) and Jackman and Miller (1995), turnout should decrease as the number of parties rises. As executives must form coalitions to govern, responsibility for government becomes diffuse. Unable to hold a party accountable, citizens refrain from voting. Again, we calculate the effective number of parties by department and assign this number to each municipality within its borders.

A fourth institutional factor we employ is one that is commonly called closeness, which varies inversely with turnout. Following Cox (1988), we measure closeness by identifying the difference in votes received by the two largest parties in each municipality divided by the total number of eligible voters, multiplied by 100 to create a percentage. This then represents the percentage of additional eligible votes that would be needed by the second place finisher to become the first place finisher. The lower the percentage the closer the election and we expect this coefficient to be negative. Finally, we expect the number of eligible voters to vary positively with turnout because parties will make extra efforts to mobilize voters where there are many potential voters.

We also measure the impact of three factors that reflect spatial-institutional differences among municipalities. Since polling stations are only located in municipal capitals, we hypothesize that participation should drop as the distance needed to travel to vote increases. We measure size as the number of square kilometers $(\mathrm{km} 2)$ in a municipality. We also hypothesize that turnout should vary inversely with the time needed to stand in line to cast their ballots. Following legal procedure, we operationalize polling station waiting time as the ratio of registered voters to voting stations (data are from the Tribunal Supremo Electoral); turnout should increase as this ratio falls.

We also test for the effects of geographic concentration. We hypothesize that turnout rates will be higher in departmental capitals because their population densities are higher. Parties will have more incentives to mobilize voters on election day in these municipalities. We use a dummy variable to operationalize this variable with departmental capitals being scored a " 1 " and all other municipalities being scored a "0." This article calculates turnout as the number valid, annulled, and blank votes as a share of the eligible population in each municipality (whose 
methods we describe in Appendix A), thus producing the first set of such estimates for Guatemala or any other developing country. These estimates also allow us to correct for over response rate of more than $40 \%$; in existing surveys, $73 \%$ of respondents said they voted in the 1995 elections (Development Associates, 1996, 2000). ${ }^{2}$ Table 2 contains descriptive statistics for all of our dependent and independent variables.

\section{The determinants of voter turnout rates: an empirical analysis}

We use ordinary least squares (OLS) regression to construct nine models of voter turnout in the 1985, 1990, and 1995 presidential, legislative, and presidential runoff elections. Tables 3-5 present the findings of our models. Adjusted R2 of approximately 0.5 indicates that the models are well-specified. Residuals are normally distributed and we only detect one problem with multicollinearity. The final set of models does not contain the vote-seat deviation variable because it was highly correlated with the effective number of parties $(r=0.951$ for $1995, \mathrm{r}=$ 0.780 for 1990 , and $r=0.744$ for 1985 ).

Several students of turnout rates recommend against using OLS models because the dependent variable is censored - restricted to values of 0.01 to 1 - and thus may deflate the T-values of individual parameters, especially if it is not normally distributed (e.g., Heckelman, 1995). We use what Maddala (1983: 29-30) calls the Minimum Logit Chi-Square Method to see whether this is a problem. ${ }^{3}$ Comparison of the OLS with these logged models, however, reveals only superficial differences between them.

\section{Discussion}

Our models suggest that institutional and spatial variables consistently shape municipal-level turnout rates. Indeed, the findings suggest that even fewer Guatemalans would have turned out to vote if their municipalities had not been small in size and possessed a low registered voter to voting station ratio. Our models also show that the sociological characteristics of municipalities are related to turnout levels, though in unexpected ways. The gender variable is consistently and significantly related to turnout: as the share of registered voters who are females increases, overall turnout increases. As voter turnout rates have fallen through time, however, the models show a decline in the importance of economic development

\footnotetext{
2 We thank Mitchell A. Seligson for supplying us with this information.

3 The formula is straightforward: $\operatorname{Ln}(\mathrm{p} / 1-\mathrm{p})$ where $\operatorname{Ln}$ is the natural $\log$ and $\mathrm{p}$ is the share of value in question needing transformation. We thank John T. Williams for bringing this to our attention.
} 
Table 3

Regression models of voter turnout rates in presidential elections

\begin{tabular}{|c|c|c|c|}
\hline & 1985 & 1990 & 1995 \\
\hline \multicolumn{4}{|l|}{ Independent variables } \\
\hline Constant & $34.181^{* * * *}(4.860)$ & $40.218^{* * * *}(6.161)$ & $75.419^{* * * *}(11.449)$ \\
\hline \multicolumn{4}{|l|}{ Sociological variables } \\
\hline Urban population & $0.163^{* * * *}(0.028)$ & $0.044(0.030)$ & $0.0245(0.035)$ \\
\hline Indigenous population & $-0.019(-0.017)$ & $-0.033^{*}(0.018)$ & $-0.658^{* * *}(0.021)$ \\
\hline $\begin{array}{l}\text { Electricity (as a share of all } \\
\text { households) }\end{array}$ & $-0.084^{*}(0.047)$ & $0.025(0.032)$ & $-0.009(0.035)$ \\
\hline $\begin{array}{l}\text { Females (as a share of } \\
\text { registered voters) }\end{array}$ & $0.472^{* * * *}(0.048)$ & $0.538^{* * * *}(0.062)$ & $0.740^{* * * *}(0.080)$ \\
\hline $\begin{array}{l}\text { Literates (as a share of } \\
\text { registered voters) }\end{array}$ & $-0.006(0.044)$ & $-0.011(0.046)$ & $-0.191^{* * * *}(0.053)$ \\
\hline \multicolumn{4}{|l|}{ Institutional variables } \\
\hline District magnitude & $0.467(0.355)$ & $0.121(0.463)$ & $-2.041^{* * * *}(0.534)$ \\
\hline Eligible voters & $-0.00002^{*}(0.000)$ & $-0.00002^{*}(0.000)$ & $-0.00002^{* *}(0.000)$ \\
\hline Effective number of parties & $-1.461^{* *}(0.655)$ & $-2.594^{* * *}(0.999)$ & $0.421(1.015)$ \\
\hline Closeness & $0.367^{* * * *}(0.076)$ & $0.472^{* * * *}(0.142)$ & $0.659^{* * * *}(0.139)$ \\
\hline \multicolumn{4}{|l|}{ Spatial-institutional variables } \\
\hline Size of municipality $\left(\mathrm{km}^{2}\right)$ & $-0.0007(0.001)$ & $-0.003^{* * * *}(0.001)$ & $-0.002^{* * *}(0.001)$ \\
\hline $\begin{array}{l}\text { Ratio of registered voters to } \\
\text { voting stations }\end{array}$ & $-0.011(0.007)$ & $-0.024^{* * *}(0.008)$ & $-0.085^{* * * *}(0.017)$ \\
\hline Departmental capital & $5.579^{* * *}(2.259)$ & $2.102(2.072)$ & $-0.332(2.341)$ \\
\hline$N$ & 326 & 326 & 329 \\
\hline Adj. $R^{2}$ & 0.489 & 0.471 & 0.477 \\
\hline
\end{tabular}

Note: Standard errors are in parenthesis.

***** $p \leqslant 0.001$

*** $p \leqslant 0.01$.

*** $p \leqslant 0.05$.

${ }^{*} p \leqslant 0.10$.

and geographic location (urban vs. rural). They also reveal that, by 1995, literacy and indigenousness were becoming negatively related to turnout.

We find that the female share of registered voters varies positively with turnout. This variable also is the most important of all sociological factors: for every percentage increase in the share of registered females, turnout goes up between half and nearly 1\%. Like Power and Roberts (1995), who find that the share of females in the labor force (their surrogate for the impact of modernization on women) was positively related to turnout rates in Brazil, we interpret this to mean that political participation varies with the prominence of women in society.

The other sociological variables have contradictory impacts on turnout rates. As a share of registered voters, literacy is only statistically significant in the 1995 presidential and legislative elections. Yet, in contrast to sociological arguments, literacy is negatively related turnout: for every percentage increase in the numbers of literate registered voters, turnout decreases by approximately one-fifth of a percentage 
Table 4

Regression models of voter turnout rates in legislative elections

\begin{tabular}{|c|c|c|c|}
\hline & 1985 & 1990 & 1995 \\
\hline \multicolumn{4}{|l|}{ Independent variables } \\
\hline Constant & $34.515^{* * * *}(4.858)$ & $43.800^{* * * *}(6.055)$ & $79.281^{* * * *}(11.369)$ \\
\hline \multicolumn{4}{|l|}{ Sociological variables } \\
\hline Urban population & $0.162^{* * * *}(0.028)$ & $0.042(0.031)$ & $0.035(0.035)$ \\
\hline Indigenous population & $-0.020(0.018)$ & $-0.039^{* *}(0.018)$ & $-0.071^{* * * *}(0.021)$ \\
\hline $\begin{array}{l}\text { Electricity (as a share of all } \\
\text { households) }\end{array}$ & $-0.084^{*}(0.046)$ & $0.028(0.032)$ & $-0.001(0.035)$ \\
\hline $\begin{array}{l}\text { Females (as a share of } \\
\text { registered voters) }\end{array}$ & $0.478^{* * * *}(0.048)$ & $0.547^{* * * *}(0.062)$ & $0.748^{* * * *}(0.080)$ \\
\hline $\begin{array}{l}\text { Literates (as a share of } \\
\text { registered voters) }\end{array}$ & $-0.013(0.044)$ & $-0.023(0.046)$ & $-0.201^{* * * *}(0.054)$ \\
\hline \multicolumn{4}{|l|}{ Institutional variables } \\
\hline District magnitude & $0.491(0.355)$ & $0.177(0.466)$ & $-1.431^{* * *}(0.581)$ \\
\hline Eligible voters & $-0.00002^{*}(0.000)$ & $-0.00002^{*}(0.000)$ & $-0.00002^{* *}(0.000)$ \\
\hline Effective number of parties & $-1.583^{* * *}(0.650)$ & $-2.800^{* * *}(1.002)$ & $0.264(1.022)$ \\
\hline Closeness & $0.375^{* * * *}(0.080)$ & $0.367^{* * *}(0.141)$ & $0.619 * * * *(0.143)$ \\
\hline \multicolumn{4}{|c|}{ Spatial-institutional variables } \\
\hline Size of municipality $\left(\mathrm{km}^{2}\right)$ & $-0.0008(0.001)$ & $-0.003^{* * * *}(0.001)$ & $-0.002^{* * *}(0.001)$ \\
\hline $\begin{array}{l}\text { Ratio of registered voters to } \\
\text { voting stations }\end{array}$ & $-0.011(0.007)$ & $-0.028^{* * * *}(0.008)$ & $-0.095^{* * * *}(0.017)$ \\
\hline Departmental capital & $5.993^{* * *}(2.262)$ & $2.633(2.089)$ & $0.250(2.354)$ \\
\hline$N$ & 326 & 326 & 329 \\
\hline Adj. $R^{2}$ & 0.483 & 0.464 & 0.471 \\
\hline
\end{tabular}

Note: Standard errors are in parenthesis.

**** $p \leqslant 0.001$.

*** $p \leqslant 0.01$.

${ }^{* *} p \leqslant 0.05$.

${ }^{*} p \leqslant 0.10$.

point. Only for the 1985 elections are the percent of the population that lives in urban areas, and the percent of households having access to electricity statistically significant and positively related to turnout. That these variables become statistically insignificant in later elections suggests that a hypothesis worth exploring is whether political disenchantment among more urban and more economically developed voters may be fueling increases in voter abstention rates.

The share of the municipal population that is indigenous is negatively related to turnout. Its statistical significance increases with time and is most apparent in presidential elections. By the 1995 presidential elections, turnout falls by more than one-half of a percentage point for every percentage increase in the municipal population that is indigenous. Curiously, its effects are barely noticeable in legislative and presidential runoff elections. This suggests that parties may be fielding candidates more attractive to indigenous voters in multimember legislative contests than 
Table 5

Regression models of turnout rates in presidential runoff elections

\begin{tabular}{|c|c|c|c|}
\hline & 1985 & 1990 & 1995 \\
\hline \multicolumn{4}{|l|}{ Independent variables } \\
\hline Constant & $24.825^{* * * *}(4.508)$ & $19.824^{* * * *}(4.928)$ & $28.751^{* * * *}(7.726)$ \\
\hline \multicolumn{4}{|l|}{ Sociological variables } \\
\hline Urban population & $0.121^{* * * *}(0.026)$ & $0.016(0.026)$ & $0.012(0.024)$ \\
\hline Indigenous population & $-0.034^{* *}(0.016)$ & $-0.009(0.015)$ & $-0.028^{* *}(0.015)$ \\
\hline $\begin{array}{l}\text { Electricity (as a share of all } \\
\text { households) }\end{array}$ & $-0.051(0.043)$ & $0.064^{* *}(0.027)$ & $0.019(0.025)$ \\
\hline $\begin{array}{l}\text { Females (as a share of regis- } \\
\text { tered voters) }\end{array}$ & $0.354^{* * * *}(0.046)$ & $0.322^{* * * * *}(0.054)$ & $0.341^{* * * *}(0.056)$ \\
\hline $\begin{array}{l}\text { Literates (as a share of regis- } \\
\text { tered voters) }\end{array}$ & $0.014(0.040)$ & $0.056(0.038)$ & $0.036(0.037)$ \\
\hline \multicolumn{4}{|l|}{ Institutional variables } \\
\hline District magnitude & $0.046(0.336)$ & $0.570(0.388)$ & $-0.438(0.404)$ \\
\hline Eligible voters & $-0.00001(0.000)$ & $-0.00002^{* *}(0.000)$ & $-0.00001^{* *}(0.000)$ \\
\hline Effective number of parties & $-0.939(0.663)$ & $-3.115^{* * * *}(0.832)$ & $-0.962(0.709)$ \\
\hline Closeness & $0.480^{* * * *}(0.045)$ & $0.431^{* * * *}(0.072)$ & $0.587^{* * * *}(0.094)$ \\
\hline \multicolumn{4}{|l|}{ Spatia-institutional variables } \\
\hline Size of municipality $\left(\mathrm{km}^{2}\right)$ & $-0.001^{* *}(0.001)$ & $-0.002^{* * * *}(0.001)$ & $-0.001^{* *}(0.001)$ \\
\hline $\begin{array}{l}\text { Ratio of registered voters to } \\
\text { voting stations }\end{array}$ & $-0.0009(0.006)$ & $-0.008(0.006)$ & $-0.030^{* * *}(0.012)$ \\
\hline Departmental capital & $6.70^{* * * *}(2.084)$ & $6.313^{* * *}(1.747)$ & $4.065^{* * *}(1.642)$ \\
\hline$N$ & 326 & 326 & 329 \\
\hline Adj. $R^{2}$ & 0.608 & 0.521 & 0.489 \\
\hline
\end{tabular}

Note: Standard errors are in parenthesis.

**** $p \leqslant 0.001$.

*** $p \leqslant 0.01$.

*** $p \leqslant 0.05$.

in presidential races. Furthermore, the stakes of not participating may become clearer for parties, indigenous organizations, and voters themselves in runoff elections, where participation is restricted to the two presidential candidates obtaining the most votes.

Even after for controlling for a host of sociological factors, the spatial-institutional variables have the most consistent effects on turnout. Turnout rates decline as both the size of a municipality and the ratio of voters to voting stations increases. The performance of both variables indicates that as the distance and time needed to cast a ballot goes up, voters are less willing to go to the trouble of voting. In addition, the over-time ratio of registered voters per voting station increases in its impact on turnout, and suggests another factor contributing to overall declines in voter turnout. This variable is not statistically significant in 1985, suggesting that Guatemalans were willing to endure long lines to vote in the first post-transition elections. By 1995, however, turnout decreases by almost $1 \%$ for every increase in 10 registered voters assigned to a voting station in the legislative balloting.

Closeness, as measured by the difference in votes received between the top two vote receiving parties, is statistically significant in all elections and all years. Voter turnout rates, however, actually increase for every percentage increase in the difference of votes separating first from second place winners in Guatemala in all types of elections. The impact of closeness on turnout 
also increases with time or as turnout rates fall across the country. Turnout goes from increasing by an average of $0.406 \%$ in 1985 in all three elections to an average of $0.621 \%$ in all three 1995 elections. Similarly, turnout actually falls as the number of eligible voters increases. Though its effect is small - never more than a quarter to a third of a percentage point at the mean number of eligible voters - its effect increases with time because of the increasing number of eligible voters and the coefficient remains unchanged $(-0.00002)$.

The unexpectedly positive relationship between closeness and turnout as well as the surprisingly negative relationship between eligible voters and turnout both suggest that parties and voters are not worried about affecting national-level trends in their municipalities. First, that about half of all voters live in often remote rural areas and that polls show an urban bias suggests that parties and votes may have little information about the closeness of the race. Second, machine politics may be alive and well, especially in rural areas of the country. Locally powerful parties mobilize their supporters by, for example, providing them with free transportation to polling locations for non-strategic reasons. The increasing importance of this variable over time also suggests that machine politics remain salient as independent voters become increasingly disenchanted with politics.

\section{Conclusions and implications}

In this paper, we use a subnational research design that varies both sociological and institutional factors across a large $\mathrm{N}$ of cases. We examine the newly democratizing country of Guatemala because it contains a great deal of ethnic, social, and economic diversity among its 330 municipalities. In line with the cross-national study of Anibal Pe'rez-Liñan (2001) of Latin American democracies, we find that the institutional and spatial variables do shape voter turnout rates. In most elections, turnout declines with the number of effective parties. All else being equal, more citizens turn out to vote as the size of a municipality decreases. Voters also cast ballots if their polling stations - which are only located in municipal capitals - contain larger numbers of voting stations. Contrary to theoretical expectations, turnout is greatest where political competition is the least intense. That the closeness between first and second place winners at the municipal level is positively associated with turnout suggests that local political machines mobilize voters for non-strategic reasons. And, in presidential runoff elections, parties seem to be concentrating their efforts on mobilizing voters in departmental capitals - a place where a disproportionate number of citizens live.

Social structure, however, still counts. Our models show that municipalities with larger numbers of registered females voters have higher turnout rates than those with fewer women registered to vote, even if fewer women are registered to vote and, as a result, actually cast ballots. Economic development and geographic location (urban vs. rural), however, have little discernible impact on turnout. And, as turnout rates have fallen through time (at both the national and municipal levels), the share of registered voters who are literate and the share of the population that is indigenous have become negatively associated with turnout.

The implications of these findings become apparent once we recognize that, as of this writing, electoral reform appears to be going nowhere in Guatemala. In June 1998, the Peace Accordsapproved Electoral Reform Commission (consisting of members of Congress and the Supreme Electoral Tribunal) recommended overhauling the electoral registry to create a national, 
computer-based, photographic ID card system (Comisio'n de Reforma Electoral, 2000). It also suggested that polling stations be located throughout the country, not just in municipal capitals.

The Electoral Reform Commission's report suggests that many political observers believe there is a link between laws and turnout levels - a relationship we empirically document in this paper. The failure to enact reforms therefore seems to benefit existing parties and higher income groups least interested in mobilizing Guatemala's largely poor, often illiterate, and frequently indigenous voters. Guatemalan parties may find it easier to attract the support of likely voters than to persuade citizens to register and to mobilize them on election day. That wealthy Guatemalans have not historically championed democracy (and much less encouraged the state to spend money on human development) suggests that they also have little interest in increasing voter turnout rates.

Like many other developing countries, Guatemala appears to be stuck in an unpleasant political equilibrium. Increasing turnout might put more pressure on elected officials to comply with the 1996 Peace Accords, which called for rapidly increasing state spending on health, education, and social welfare - investments that could spur interest in government. Despite the commitment in the 1996 Peace Accords to increase taxes, spending on development remains limited because central government revenues amount to less than 10\% of GDP, placing Guatemala among the least-taxed countries in the world (SNUG, 1999: 37-43). Low levels of social spending, along with a historically unstable and repressive political system, in turn encourage political passivity. Between 1993 and 1999, Development Associates (2000: 18-9) estimates support of the system has remained stagnated at around 40\% - making Guatemala one of the least supported systems in the Americas (Lagos, 1997). Indeed, our findings help to explain why the Inter-American Development Bank (IDB, 2000: 163-99) finds that there is a strong positive relationship between turnout, government spending, and interest in politics. Until political conditions change, however, Guatemala will have the dubious honor of being the country that proves how dismal this relationship can get.

\section{Acknowledgements}

Kirk Bowman, Matthew Clearly, Josep Colomer, Mark P. Jones, Arend Lijphart, Stephen Perz, Anibal Pe'rez-Liñan, and David Samuels made valuable comments on earlier drafts of this article. George Alter, Erwin Diaz, and David Dodds helped us to produce estimates of the voting age population, for which we are very grateful. We thank the GIS staff at the Universidad del Valle, Guatemala City, for furnishing us with the digitized base maps of their country and Aida Vaca-Guzma'n, Anthony Richey, and Cynthia Yaudes for data entry. Lehoucq acknowledges the National Science Foundation (SBR-9521918) for support.

\section{Appendix A}

We use demographic estimates of the municipal-level voting age populations because registering to vote is not automatic and leads to inflated turnout rates. On average, approximately $70 \%$ of the electorate, at the national level, appears to be registered to vote. Furthermore, Boneo and TorresRivas (2000: 46-58) show that the electoral registry has $25 \%$ more names than it should because of immigration to the US, to other municipalities, and death. Finally, by the 1999 elections, 36\% of the eligible voters were not registered to vote. 
The first step in generating estimates of the voting-age population consists of extrapolating from the 1981 (DGE, 1982b) and 1994 (INE, 1995) population censuses. Thankfully, the latter contains detailed age pyramids at the municipal level. The former does not; it broke down the municipal age structure into the following cohorts: $0-4,5-9,10-14,15-19,20+$. Because there is no 20-24 cohort in the 1981 census, we could not use the Karup-King formula for estimating the number of 18 and 19 years, which we could have simply added to all 20+ groupings.

Our estimate of the 18 and 19 year olds was based on a more intuitive procedure. We simply multiply each municipality's 1981 report of the 15-19 cohort by the share of the 18 and 19 years of this cohort at the national level, for which an age pyramid exists. This yields numbers that we add to the last cohort to estimate the size of the electorate in 1981. Since the National Institute of Statistics (INECELADE, 1997: 35) estimates that the undercount rate for 1981 is $12.9 \%$ and that for the more recent census is $13.8 \%$, we divide the figures for each municipality for each of these years by the omission rate. This produces a number that we add to each municipality's voting age population. With these numbers, we estimate growth rates for each municipality between 1981 and 1994 using the following formula:

$$
r=1 / t * \ln \left(P_{\mathrm{t}} / P_{0}\right)
$$

where $t$ is the year for which the estimate is needed, $\ln$ is the natural log and Pt is the 1994 census count and P0 is the census count for 1981. And, with these numbers, we estimate the size of the municipal electorate with the following formula:

$$
P_{t}=P_{0} e^{r t}
$$

where $\mathrm{P}_{0}$ is the 1981 voting age population, $\mathrm{e}$ is the natural growth constant $(2.71828), \mathrm{r}$ is the growth rate, and $t$ is the number of years and months since the last census count. For the 1985 and 1990 estimates, $t$ is from the 1981 census; for 1995, it is from the 1994 census.

There are a small number of municipalities where our estimate of the voting age population is less than the registered number of citizens, facts consistent with a deficient registry that includes the names of dead voters $(6.7 \%)$, citizens who have left their municipality of registration (6\%), or have not completed the registration process (12\%) (Boneo and Torres-Rivas, 2000: 51-5). There are 7, 13, and 42 cases in 1985, 1990, and 1995 where the average rate of underestimation for these municipalities is $105 \%, 107.4 \%$, and $110 \%$, respectively. Correlations between our estimates and the numbers of registered voters are extraordinarily high $(r=0.995$ for $1995 ; r=0.995$ for $1990 ; r=0.993$ for 1985$)$. In our models, we truncated these numbers at $100 \%$.

\section{References}

Agnew, J., 1996. Mapping politics: how context counts in electoral geography. Political Geography 15, 129-146.

Boneo, H., Torres-Rivas, E., 2000. Por que' no votan los guatemaltecos? Estudio de participación y abstención electoral. IDEA, Tribunal Supremo Electoral, and PNUD, Guatemala City. Colomer, J.M., 1991. Benefits and costs of voting. Electoral Studies 31, 313-325.

Comisión de Reforma Electoral, 2000. Guatemala, Paz y Democracia: Informe de la Comisión de Reforma Electoral, second ed.. Litografi'a CIFGA, Guatemala City.Reforma Electoral, second ed.. Litografi'a CIFGA, Guatemala City.

Cox, G.W., 1988. Closeness and turnout: a methodological note. Journal of Politics 50, 768-775. 
Cox, G.W., 1999. Electoral rules and the calculus of mobilization. Legislative Studies Quarterly 24, 387-419.

Development Associates, Inc.,1996. La cultura democrática de los Guatemaltecos: segundo estudio. Guatemala, n.p.

Development Associates, Inc., 2000. La cultura democrática de los Guatemaltecos: cuarto estudio, 1999. Guatemala, n.p.

Dirección General de Estadistica (DGE), 1982a. IV Censo de Habitación: Locales de Habitación, Particulares y Colectivos, Hogares. Tomo I vol. I. DGE, Guatemala City.

Dirección General de Estadistica (DGE), 1982b. IX Censo de Población: Población Total e Indigena. Tomo I vol. II. DGE, Guatemala City.

Dorling, D.F.L., Johnson, R.J., Pattie, C.J., 1996. Using triangular graphs for representing, exploring and analyzing electoral change. Environment \& Planning A 28, 979-999.

Heckelman, J.C., 1995. The effect of the secret ballot on voter turnout rates. Public Choice 82, 107-124. Hodge, D., Staeheli, L., 1992. Social relations and geographic patterns of urban electoral behavior. Urban Geography 48, 14-27.

Institute for Democracy and Electoral Assistance (IDEA), 1997. Voter Turnout From 1945 to 1997: A Global Report on Political Participation. IDEA, Stockholm. Instituto Nacional de Estadistica (INE), 1995. X Censo de Población. INE, Guatemala City. Instituto Nacional de Estadistica (INE) \& Centro Latinoamericano de Demografi'a (INECELADE),Instituto Nacional de Estadistica (INE) \& Centro Latinoamericano de Demografi'a (INE-CELADE),

1997. Guatemala: Estimaciones y Proyecciones de Población, 1950-2050. INE-CELADE, Guatemala

City.

Inter-American Development Bank (IDB), 2000. Development, Beyond Economics: Economic and Social Progress in Latin America, 2000 Report. Inter-American Development Bank, Washington, DC.

Jackman, R.W., 1987. Political institutions and voter turnout in the industrial democracies. American Political Science Review 81, 405-423.

Jackman, R.W., Miller, R.A., 1995. Voter turnout in the industrial democracies during the 1980s. Comparative Political Studies 27, 467-492.

Laakso, M., Taagepera, R., 1979. The Effective Number of Parties: A Measure with Application to Western Europe. Comparative Political Studies 12, 3-27.

Lagos, M., 1997. Latin America’s smiling mask. Journal of Democracy 8, 125-138.

Lehoucq, F., 2002. The 1999 general elections in Guatemala. Electoral Studies 21, 107-114.

Lijphart, A., 1994. Electoral Systems and Party Systems: A Study of Twenty-Seven Democracies, 1945-1990. Oxford University Press, New York and London.

Lijphart, A., 1997. Unequal participation: democracy's unresolved dilemma. American Political Science Review 91, 1-14.

Maddala, G.S., 1983. Limited-Dependent and Qualitative Variables in Econometrics. Cambridge University Press, Cambridge.

Pe'rez-Lin an, A., 2001. Neoinstitutional accounts of voters turnout: moving beyond industrial democracies. Electoral Studies 20, 281-297.

Powell, Jr.., G.B., 1986. American voter turnout in comparative perspective. American Political Science Review 80, 17-43. 
Power, T.J., Roberts, J.T., 1995. Compulsory voting, invalid ballots, and abstention in Brazil. Political Research Quarterly 48, 795-826.

Seligson, M.A. (forthcoming). Democracy on ice: the multiple paradoxes of Guatemala's peace process. In: Hagopian, F., Mainwaring, S. (Eds.), Advances and Setbacks in the Third Wave of Democratization in Latin America. Cambridge University Press, New York.

Seligson, M.A., Conroy, A., Co'rdova-Macias, R., Pe'rez, O.J., Stein, A.J., 1995. Who votes in Central America? A comparative analysis. In: Seligson, Mitchell A., Booth, John A. (Eds.), Elections and Democracy in Central America Revisited. University of North Carolina Press, Chapel Hill.

SNUG (Sistema de Naciones Unidas en Guatemala), 1999. Guatemala: el rostro rural del desarrollo humano 1999. PNUD, Guatemala City.

Smith, C.A. (Ed.), 1990. Guatemalan Indians and the State, 1540-1988. University of Texas Press, Austin.

Tribunal Supremo Electoral (TSE), 1986. Memoria de las Elecciones Generales-1985, 1990, 1995. TSE, Guatemala City.

Verba, S., Nie, N.H., 1972. Participation in America: Political Democracy and Social Equality. Harper \& Row, New York.

Wolfinger, R.E., Rosenstone, S.J., 1980. Who Votes? Yale University Press, New Haven. 